\title{
KESIAPSIAGAAN SEKOLAH TERHADAP POTENSI BENCANA BANJIR DI SDN GEBANGMALANG KECAMATAN MOJOANYAR KABUPATEN MOJOKERTO
}

\author{
Heti Aprilin ${ }^{1}$,Setya Haksama ${ }^{2}$, Makhfludi ${ }^{3}$ \\ ${ }^{1}$ Mahasiswa Program Studi Magister Manajemen Bencana Sekolah Pascasarjana \\ Universitas Airlangga Surabaya \\ ${ }^{2}$ Fakultas Kesehatan Masyarakat Universitas Airlangga Surabaya \\ ${ }^{3}$ Fakultas Keperawatan Universtas Airlangga Surabaya \\ Email :h.aprilin@gmail.com
}

\begin{abstract}
ABSTRAK
Kesiapsiagaan merupakan salah satu proses manajemen bencana, pentingnya kesiapsiagaan merupakan salah satu elemen penting dari kegiatan pencegahan pengurangan risiko bencana. Kegiatan yang dilakukan sebagai upaya antisipasi dan pengurangan risiko bencana dapat berupa pengetahuan yang dimiliki seseorang dan sikap yang dilakukan. Pada tempat penelitian SDN Gebangmalang 1 dan 2 Kecamatan Mojoanyar Kabupaten Mojokerto kurang memahami dalam menghadapi kesiapsiagaan bencana banjir karena ketidaktahuan tentang dampak bencana. Tujuan penelitian ini menganalisis kesiapsiagaan sekolah terhadap kesiapsiagaan bencana banjir di SDN Gebangmalang Kecamatan Mojoanyar kabupaten Mojokerto. Jenis penelitian ini adalah penelitian survey yang bersifat explanatory. Sampel penelitian ini adalah guru dan orangtua yang berjumlah 77 orang. Pengambilan sampel diambil semua (Total Sampling). Instrumen Pengumpulan Data diambil menggunakan kuesioner dan dianalisa dengan uji statistik spearman's rho dengan taraf kesalahan $\alpha=0,05$. Hasil penelitian setelah dilakukan uji statistik spearman's rho diperoleh nilai sig. (2-tailed) atau $\mathrm{p}$ value 0,000 (karena $\mathrm{p}$ value <0,05) maka ada hubungan kesiapsiagaan guru dan orangtua terhadap potensi bencana banjir. Bagi pemerintah Kabupaten Mojokerto dan Badan Penanggulangan Bencana Daerah (BPBD) dapat bekerjasama dengan dinas pendidikan di wilayah kecamatan mojoanyar kabupaten mojokerto untuk memberikan sosialisasi dan informasi yang terintegrasi sehingga guru dan orangtua dapat mendapatkan awareness dan preparedness yang lebih baik untuk menghadapi ancaman bencana banjir di kecamatan Mojoanyar Kabupaten Mojokerto
\end{abstract}

Kata Kunci : Kesiapsiagaan Sekolah, Potensi, Bencana, Banjir 


\begin{abstract}
Preparedness is one of the management process, the importance of disaster preparedness is one of the important elements of preventive disaster risk reduction activities. Activities performed as an attempt of anticipation and disaster risk reduction can be a knowledge attitude and a person owned. Research on the place of SDN Gebangmalang 1 and 2 Kecamatan Mojoanyar Mojokerto less understanding in the face of disaster preparedness of flooding due to ignorance about the impact of this research Aim to analyze disaster preparedness school disaster preparedness against flood in Mojoanyar Subdistrict Gebangmalang SDN Mojokerto. purpose and in particular to analyze the relationship of knowledge, attitude, action and perception of risk preparedness against flood disaster preparedness diSDN Gebangmalang 1 and 2 Kecamatan Mojoanyar Mojokerto. This type of research is explanatory research survey that is. The sample of this research is the teachers and parents of 77 people. Sampling is taken all the (Total Sampling). Data collection instruments are taken using a questionnaire and analyzed with statistical tests spearman's rho with $\alpha=0.05$ level errors. Research results after a test statistic spearman's rho retrieved the value of the sig (2-tailed) or $\mathrm{p}$ value 0.000 (because $\mathrm{p}$ value $<0.05$ ) then there is a relationship of teacher and parent's preparedness against a potential flooding disaster. For Government Agencies and Mojokerto Disaster area (BPBD) in collaboration with the Office of education in region kecamatan mojoanyar mojokerto to provide socialization and information are integrated so that teachers and parents can get the awareness and better preparedness to deal with the threat of flood in district Mojoanyar Mojokerto
\end{abstract}

Keywords : school preparedness, potential, disaster, flood. 


\section{PENDAHULUAN}

Kesiapsiagaan terhadap bencana merupakan rangkaian tindakan, persiapan serta kegiatan yang dilakukan baik di tatanan individu, kelompok atau masyarakat dalam menghadapi dan mengantisipasi setiap ancaman bencana yang mengancam kelangsungan hidup melalui upaya pengorganisasian yang terencana, tepat guna dan berdaya guna (UndangUndang Nomor 24 tahun 2007). Kesiapsiagaan merupakan salah satu mekanismes penanggulangan bencana serta sebagai upaya untuk antisipasi dan pengurangan akibat terjadinya resiko bencana. Kegiatan yang dilakukan untuk peningkatan kesiapsiagaan adalah dengan cara peningkatan pengetahuan dan sikap yang dilakukan masyarakat.

Pengetahuan yang dimiliki oleh seseorang atau masyarakat merupakan salah satu kunci utama dari konsep kesiapsiagaan. Pengetahuan yang dimiliki oleh seseorang atau masyarakat secara tidak langsung akan mempengaruhi sikap dan perilaku terutama dalam mengantisipasi setiap kejadian bencana yang terjadi. Kesiapsiagaan merupakan faktor penting yang menjadi fokus perhatian dewasa ini mengingat kesiapsiagaan adalah faktor penentu untuk pengurangan resiko bencana yang dapat dilakukan dan diupayakan sejak dini (LIPI-UNESCO, 2006)

Pengalaman yan

membuktikan bahwa kurangnya pengetahuan yang dimiliki, rendahkan sikap untuk melakukan antisipasi resiko terjadinya bencana, perilaku negatif untuk pencegahan bencana serta kurangnya kesiapsiagaan dalam menghdapi suatu kondisi bencana memicu untuk terjadinya peningkatan resiko saat bencana terjadi (Bakornas, 2007). Kesiapsiagaan dalam bencana dapat dikelompokkan menjadi empat parameter utama yaitu pengetahuan dan sikap, perencanaan kondisi kedaruratan, sistem peringatan dini dan mobilisasi sumber daya. Empat paramater ini merupakan penentu utama penurunan resiko akibat terjadinya bencana pada suatu wilayah. Penurunan satu parameter dapat berakibat terjadinya peningkatan resiko akibat kejadian bencana.

Edukasi mengenai resiko kejadian bencana seharusnya diberikan kepada masyarakat sejak dini. Anak usia sekolah merupakan salah satu change agent yang dapat menjadi prioritas untuk dilakukan pendidikan mengenai resiko bencana. Hal ini penting menjadi bagian karena kecenderungan orang tua akan mengikuti apa yang dilakukan oleh anak dan begitu pula sebaliknya. Berangkat dari hal ini, pendidikan terkait resiko bencana harus diberikan sejak dini baik kepada masyarakat maupun pada anak usia sekolah. Anak usia sekolah dirasa penting untuk diberikan pendidikan mengenai resiko bencana karena aktivitas yang mereka lakukan juga berpotensi membutuhkan kesiapsiagaan saat bencana terjadi. Pada saat anak beraktivitas di sekolah, bencana dapat beresiko terjadi. Pengawasan yang dilakukan orang tua cenderung minim pada waktu anak berada di lingkungan sekolah. Salah satu bencana yang dapat dialami adalah terjadinya bencana banjir. Anak yang berada di sekolah harus siap dan siaga untuk menghadapi kondisi bencana banjir ini untuk dapat meminimalkan resiko yang dapat terjadi akibat bencana banjir (Chairummi, 2013). Hasil pengumpulan data awal yang dilakukan pada siswa di SDN Gebangmalang 1 dan SDN Gebangmalang 2 Kecamatan Mojoanyar Kabupaten Mojokerto, 
sebagian besar siswa tidak mengetahui mengenai tindakan yang harus dilakukan jika bencana banjir datang. Selama ini bencana banjir selalu dialami oleh mereka namun para siswa mengatakan jika terjadi banjir maka mereka segera lari untuk pulang dan tidak memperhatikan kondisi yang ada disekitar mereka.

Banjir merupakan bencana besar di dunia. Kejadian dan korban bencana banjir menempati urutan pertama di dunia yaitu mencapai 55\%. Persentase kejadian banjir di Indonesia mencapai $38 \%$ dari seluruh kejadian bencana. Kejadian longsor mencapai $18 \%$ dari seluruh kejadian bencana (Bakornas, 2007). Tahun 2016 Menurut BPBD Jawa Timur dilaporkan bahwa 386 kejadian bencana alam $98 \% \quad$ (376 kejadian) didominasi oleh bencana hidrometerologi yaitu tanah longsor, banjir, dan putting beliung. Angka kejadian tersebut meningkat dari tahun 2015 dengan total 287 kejadian (BPBD, 2016)

Salah satu kota di provinsi Jawa Timur yang mempunyai skor risiko tinggi terjadi bencana banjir yaitu kota Mojokerto dengan kelas risiko tinggi terjadi banjir dengan total skor 34 (IRBI, 2013).

Secara geografis wilayah Kabupaten Mojokerto terletak antara $111^{\circ} 20^{\prime} 13^{\prime \prime}$ s/d 111 ${ }^{\circ} 40^{\prime} 47^{\prime}$ 'Bujur Timur dan antara $7^{\circ} 18 ’ 35^{\prime}$ 's/d 747” Lintang Selatan.

Berdasarkan struktur tanahnya, wilayah Kabupaten Mojokerto cenderung cekung ditengah-tengah dan tinggi di bagian selatan dan utara.

Bagianselatanmerupakan wilayah pegu nungandengan kondisi tanah yang subur, yaitu meliputi Kecamatan Pacet, Trawas, Gondang, dan Jatirejo. Bagian tengahmerupakan wilayah dataran seda ng, sedangkan bagian utara merupakan daerah perbukitan kapur yang cenderung kurang subur ( Dinas komunikasi dan informatika kabupaten mojokerto, 2018).

Menurut Kepala Pelaksana BPBD Kabupaten Mojokerto M. Zaini mengatakan wilayah yang sering menjadi langganan banjir dan tanah longsor meliputi kecamatan Mojoanyar, Puri, Mojosari, Dawarblandong,Ngoro, Pungging, Jatirejo, Gondang, Pacet dan Trawas. Wilayah Mojoanyar sendiri sering terjadi banjir dikarenakan berada di aliran sungai Sadar yang sering meluap saat intensitas hujan tinggi. Sungai sadar yang mengalir ke kali Porong ini mengalami pendangkalan sehingga tida bisa menampung debit air yang besar dan normalisai dari sungai ini juga belum berjalan.

Tabel 1. Kejadian bencana banjir

\begin{tabular}{lll}
\hline Tahun & $\begin{array}{c}\text { Kejadian } \\
\text { bencana } \\
\text { banjir }\end{array}$ & $\begin{array}{c}\text { Tren kejadian } \\
\text { bencana banjir }\end{array}$ \\
\hline 2015 & 5 kali & - \\
\hline 2016 & 6 kali & $25 \%$ \\
\hline 2017 & 12 kali & $50 \%$
\end{tabular}

Sumber : BNPB / could / dibi tahun 2017

LIPI dan UNESCO pada tahun 2006 melakukan kajian ilmiah pada tiga wilayah di Indonesia yang rawan untuk terjadinya bencana yaitu Kabupaten Aceh Besar, Kota Bengkulu, dan Kota Padang. Penelitian ini bertujuan untuk melakukan kajian mengenai kesiapsiagaan terhadap kondisi bencana di lingkungan sekolah, tatanan rumah tangga dan komunitas. Dalam penelitian ini, 5 parameter kesiapsiagaan dilakukan pengkajian yaitu pengetahuan tentang bencana, kebijakan dan panduan terkait bencana, rencana tanggap darurat yang tersedia, sistem peringatan bencana yang dimiliki serta mobilisasi sumber daya. Hasil penelitian ditemukan bahwasanya tingkat kesiapsiagaan terhadap bencana 
pada lingkungan sekolah, berada di posisi paling bawah dibandingkan dengan kesiapsiagaan pada tatanan masyarakat dan organisasi yang ada. Hal ini membuktikan bahwa sekolah merupakan ruang publik yang memiliki keretanan paling tinggi untuk mengalami resiko bencana yang paling tinggi. Data yang ada mencatat bahwa gempa yang terjadi di Sumatera Barat mengakibatkan kerusakan yang besar pada lingkungan sekolah. Dampak kerusakan ini mengakibatkan terhentinya proses belajar mengajar yang dilakukan pada siswa karena bangunan sekolah mengalami kerusakan yang parah. Sarana dan prasarana di lingkungan sekolah yang dibangun selama ini tidak mengindahkan mengenai aturan tata ruang. Bangunan sekolah dibangun tanpa memprediksi struktur yang memadai untuk menghapi kondisi bencana. Selain di Sumatera Barat, banyak infrastruktur sekolah yang ada di Indonesia dibangun tanpa melakukan penghitungan serta potensi terjadinya bencana. Tidak dapat dibayangkan kerusakan dan korban yang dapat ditimbulkan jika bencana terjadi pada saat jam sekolah berlangsung.

Gempa bumi yang terjadi di Sichuan - China pada Mei 2008, memberikan bukti besarnya resiko yang dapat ditimbulkan akibat terjadinya bencana pada jam sekolah berlangsung. Gempa dengan kekuatan 7,9 skala richter memakan 87.000 korban dengan sedikitnya 5.355 murid. Hal ini menunjukkan bahwa 6\% korban yang meninggal dunia akibat bencana adalah anak usia sekolah. Laporan resmi dari pemerintah Cina, diperkirakan sebanyak 7000 bangunan sekolah runtuh dan menimbun para pelajar dan guru yang sedang beraktivitas di sekolah. Fakta lain yang dikeluarkan oleh lembaga resmi di
China, bangunan yang ada di sekitar sekolah cenderung tidak mengalami kerusakan yang cukup berarti. Hal ini membuktikan bahwa masih rendahnya perhatian yang diberikan terutama pada fasilitas pendidikan / bangunan sekolah untuk siap dalam menghadapi terjadinya bencana alam.

Dari fakta yang dikemukakan di atas, pengupayaan peningkatan kesiapsiagaan bencana pada tatanan sekolah menjadi suatu agenda penting yang harus menjadi fokus perhatian. Tanggungjawab untuk mengupayakan hal ini berada pada warga sekolah dan para pemangku kebijakan yang terkait langsung dengan dunia pendidikan. Warga sekolah adalah semua orang yang berada dan terlibat dalam kegiatan belajar-mengajar seperti murid, guru, tenaga pendidikan dan kepala sekolah. Pemangku kebijakan adalah seluruh komponen masyarakat atau organisasi dan insitusi yang berkepentingan dengan sekolah, baik warga masyarakat maupun lembaga / institusi masyarakat sekitar sekolah. Sebagai upaya untuk meningkatkan kesiapsiagaan masyarakat dalam pengurangan risiko bencana, lembaga penanggulangan bencana dalam hal ini adalah Palang Merah Indonesia (PMI) Provinsi Jawa Timur, PMI Kabupaten Mojokerto dan Badan Penanggulangan Bencana Daerah (BPBD) Kabupaten Mojokerto harus mampu untuk berkoordinasi dan saling bekerjasama

Tujuan penelitian ini adalah menganalisis kesiapsiagaan sekolah tentang kesiapsiagaan bencana banjir di SDN Gebangmalang Kecamatan Mojoanyar Kabupaten Mojokerto

\section{METODE PENELITIAN}

Penelitian ini adala penelitian survey yang bersifat explanatory. Sampel penelitian ini adalah guru dan orangtua yang berjumlah 77 orang. 
Pengambilan sampel diambil semua (Total Sampling). Instrumen Pengumpulan Data diambil menggunakan kuisioner.

\section{HASIL PENELITIAN DAN}

PEMBAHASAN

\section{Karakteristik Responden guru}

\begin{tabular}{|c|c|c|c|}
\hline $\begin{array}{l}\text { Karakterist } \\
\text { ik }\end{array}$ & Klasifikasi & $\bar{F}$ & $\begin{array}{l}\text { Persent } \\
\text { ase }\end{array}$ \\
\hline \multirow[t]{6}{*}{ Umur } & $\begin{array}{l}<30 \text { th } \\
30-40 \text { th }\end{array}$ & 4 & 4 \\
\hline & & 39 & 39 \\
\hline & $41-50$ th & & 22 \\
\hline & $>50$ th & & \\
\hline & & 35 & 35 \\
\hline & total & 100 & 100 \\
\hline \multirow{5}{*}{$\begin{array}{l}\text { Jenis } \\
\text { kelamin }\end{array}$} & Laki-laki & & 26 \\
\hline & & 26 & \\
\hline & Perempuan & 74 & \\
\hline & & & 74 \\
\hline & total & 100 & 100 \\
\hline \multirow[t]{7}{*}{ Pekerjaan } & Guru & & \\
\hline & & 100 & 100 \\
\hline & IRT & 0 & 0 \\
\hline & Wiraswasta & 0 & 0 \\
\hline & Petani & 0 & 0 \\
\hline & Lain-lain & 0 & 0 \\
\hline & total & 100 & 100 \\
\hline \multirow[t]{9}{*}{ Pendidikan } & $\mathrm{SD} / \mathrm{MI}$ & 0 & 0 \\
\hline & SLTP / MTS & & 0 \\
\hline & & 0 & \\
\hline & SMA / MA & & 0 \\
\hline & & 0 & \\
\hline & Akademi & & 100 \\
\hline & /Universitas & 100 & \\
\hline & total & & 100 \\
\hline & & 100 & \\
\hline \multirow{4}{*}{$\begin{array}{l}\text { Pengalama } \\
\mathrm{n} \\
\text { Tahun ini }\end{array}$} & Hanya satu & 57 & 57 \\
\hline & kali & & \\
\hline & $\begin{array}{l}\text { Lebih dari satu } \\
\text { kali }\end{array}$ & 43 & 43 \\
\hline & total & 100 & 100 \\
\hline \multirow{4}{*}{$\begin{array}{l}\text { Pengalama } \\
\mathrm{n} \quad \text { tahun } \\
\text { lalu }\end{array}$} & Hanya satu & & \\
\hline & kali & 35 & 35 \\
\hline & $\begin{array}{l}\text { Lebih dari satu } \\
\text { kali }\end{array}$ & 65 & 65 \\
\hline & total & 100 & 100 \\
\hline $\begin{array}{l}\text { Frekuensi } \\
\text { penyuluha } \\
\text { n }\end{array}$ & $\begin{array}{l}\text { Hanya satu } \\
\text { kali }\end{array}$ & 30 & 30 \\
\hline
\end{tabular}

\begin{tabular}{rrr}
$\begin{array}{lrr}\text { Lebih dari satu } \\
\text { kali }\end{array}$ & 70 & 70 \\
\hline total & 100 & 100 \\
\hline
\end{tabular}

Hasil pengisian kuisioner

Berdasarkan umur, hampir setengah (39\%) responden berada diusia 30-40 tahun. Menurut jenis kelamin, sebagian besar $(74 \%)$ responden berjenis kelamin perempuan. Adapun menurut pekerjaan, seluruhnya (100\%) responden bekerja sebagai guru. Menurut pendidikan, selurutnya (100\%) responden mempunyai latar belakang pendidikan terahir adalah akademi/universitas. Menurut pengalaman terkena banjir tahun ini, hampir semua (57\%) responden pernah mengalami banjir hanya satu kali. Untuk pengalaman banjir tahun lalu , hampir semua $(65 \%)$ responden pernah mengalami banjir lebih dari satu kali.Dan menurut frekuensi pernah atau tidak pernah mendapatkan penyuluhan, hampir semua (70\%) pernah mendapatkan penyuluhan lebih dari satu kali.

2. Karakteristik Responden orangtua

\begin{tabular}{llrr}
\hline $\begin{array}{l}\text { Karakteri } \\
\text { stik }\end{array}$ & Klasifikasi & F & \multicolumn{2}{c}{$\begin{array}{l}\text { Persen } \\
\text { tase }\end{array}$} \\
\hline Umur & $<30$ th & 2 & 2 \\
& $30-40$ th & & 44 \\
& $41-50$ th & & 46 \\
& $>50$ th & 46 & 7 \\
& & 7 & 100 \\
\hline Jenis & total & 100 & 100 \\
kelamin & Laki-laki & & 50 \\
& Perempuan & 50 & \\
& & & 50 \\
\hline Pekerjaan & total & 100 & 100 \\
& Guru & & 0 \\
& IRT & 0 & \\
& Wiraswasta & 41 & 41 \\
& & 13 & 13 \\
& Petani & 0 & 0 \\
& Lain-lain & 15 & 15 \\
& Swasta & 31 & 31 \\
& total & 100 & 100 \\
\hline & & &
\end{tabular}




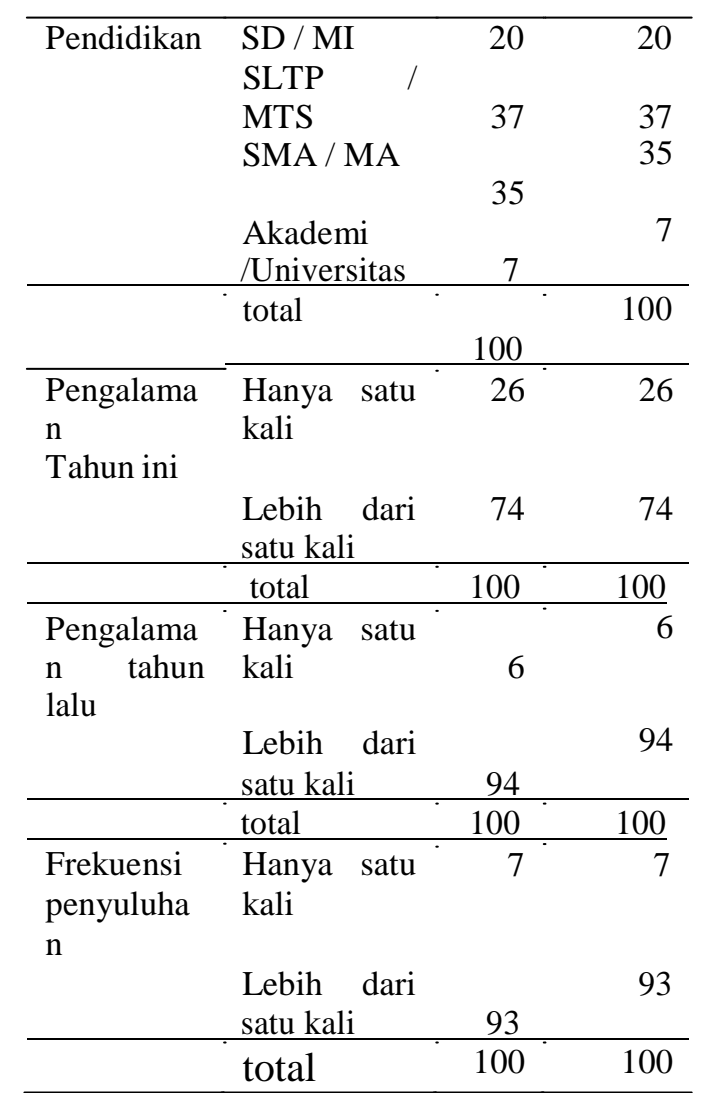

Hasil pengisian kuisioner

Berdasarkan umur, hampir setengah (46\%) responden berada diusia 41-50 tahun. Menurut jenis kelamin, sebagian besar $(50 \%)$ responden berjenis kelamin perempuan dan laki-laki.

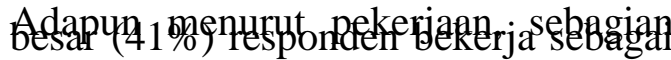
Ibu rumah tangga. Menurut pendidikan, sebagian besar (37\%) responden mempunyai latar belakang pendidikan terahir adalah SLTP/MTS. Menurut pengalaman terkena banjir tahun ini, hampir semua (74\%) responden pernah mengalami banjir lebih dari satu kali. Untuk pengalaman banjir tahun lalu , hampir semua (94\%) responden pernah mengalami banjir lebih dari satu kali.Dan menurut frekuensi pernah atau tidak pernah mendapatkan penyuluhan, hampir semua (93\%) pernah mendapatkan penyuluhan lebih dari satu kali.
Tabel 3. Kategori Penilaian Masing Masing Variabel

\begin{tabular}{|c|c|}
\hline Keterangan & Skala Penilaian \\
\hline Pengetahuan & $\begin{array}{l}<56 \% \\
\text { Kurang } \\
56 \%-75 \% \\
\text { Cukup } \\
76 \%-100 \% \quad-- \text { Baik }\end{array}$ \\
\hline Sikap (S) & $\begin{array}{l}1,00-2,49 \\
\text { Negatif } \\
2,50-4,00 \\
\text { Positif }\end{array}$ \\
\hline $\begin{array}{l}\text { Tindakan } \\
\text { kesiapsiagaan } \\
\text { (SR) }\end{array}$ & $\begin{array}{l}<56 \% \\
\text { Kurang } \\
56 \%-75 \% \\
\text { Cukup } \\
76 \%-100 \% \quad--- \text { Baik }\end{array}$ \\
\hline $\begin{array}{l}\text { Persepsi resiko } \\
\text { bencana }(\mathrm{PR})\end{array}$ & $\begin{array}{l}\text { Positif }=2,51-4,00 \\
\text { Negatif }=1,00-2,50\end{array}$ \\
\hline
\end{tabular}

Tabel 4. Statistik Deskriptif pengetahuan guru, sikap, tindakan kesiapsiagaan, persepsi resiko dan

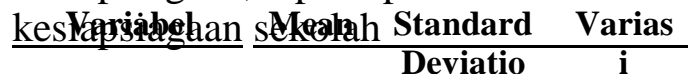

\begin{tabular}{llll} 
& \multicolumn{3}{c}{$\mathbf{n}$} \\
\hline Pengetahuan & $\begin{array}{l}87.0 \\
\%\end{array}$ & 0.75 & $\begin{array}{l}12.00 \\
\%\end{array}$ \\
\hline Sikap (S) & 59.9 & 12.06 & $\begin{array}{l}20.13 \\
\%\end{array}$ \\
\cline { 2 - 4 } & & & 91.66 \\
$\begin{array}{l}\text { Tindakan } \\
\text { kesiapsiagaan } \\
\text { (SR) }\end{array}$ & $\% 1.3$ & 3.42 & $\%$ \\
$\begin{array}{l}\text { Persepsi } \\
\text { besikgna (PR) }\end{array}$ & 29.0 & 2.81 & $9.66 \%$ \\
\hline $\begin{array}{l}\text { Kesiapsiagaa } \\
\text { n sekolah } \\
(\text { KS) }\end{array}$ & 5.72 & 2.05 & 38.76 \\
\hline
\end{tabular}

Tabel 5. Statistik Deskriptif pengetahuan orangtua, sikap, tindakan kesiapsiagaan, persepsi resiko dan kesiapsiagaan sekolah

\begin{tabular}{|c|c|c|c|}
\hline Variabel & $\begin{array}{l}\text { Mea } \\
\mathbf{n}\end{array}$ & $\begin{array}{l}\text { Standa } \\
\text { rd } \\
\text { Deviati } \\
\text { on } \\
\end{array}$ & $\begin{array}{l}\text { Varia } \\
\text { si }\end{array}$ \\
\hline $\begin{array}{l}\text { Pengetahua } \\
\text { n }\end{array}$ & $\begin{array}{l}77.8 \\
\%\end{array}$ & 1.00 & $\begin{array}{l}22.02 \\
\%\end{array}$ \\
\hline Sikap (S) & $\begin{array}{l}58.4 \\
6\end{array}$ & 5.40 & $\begin{array}{l}9.24 \\
\%\end{array}$ \\
\hline
\end{tabular}




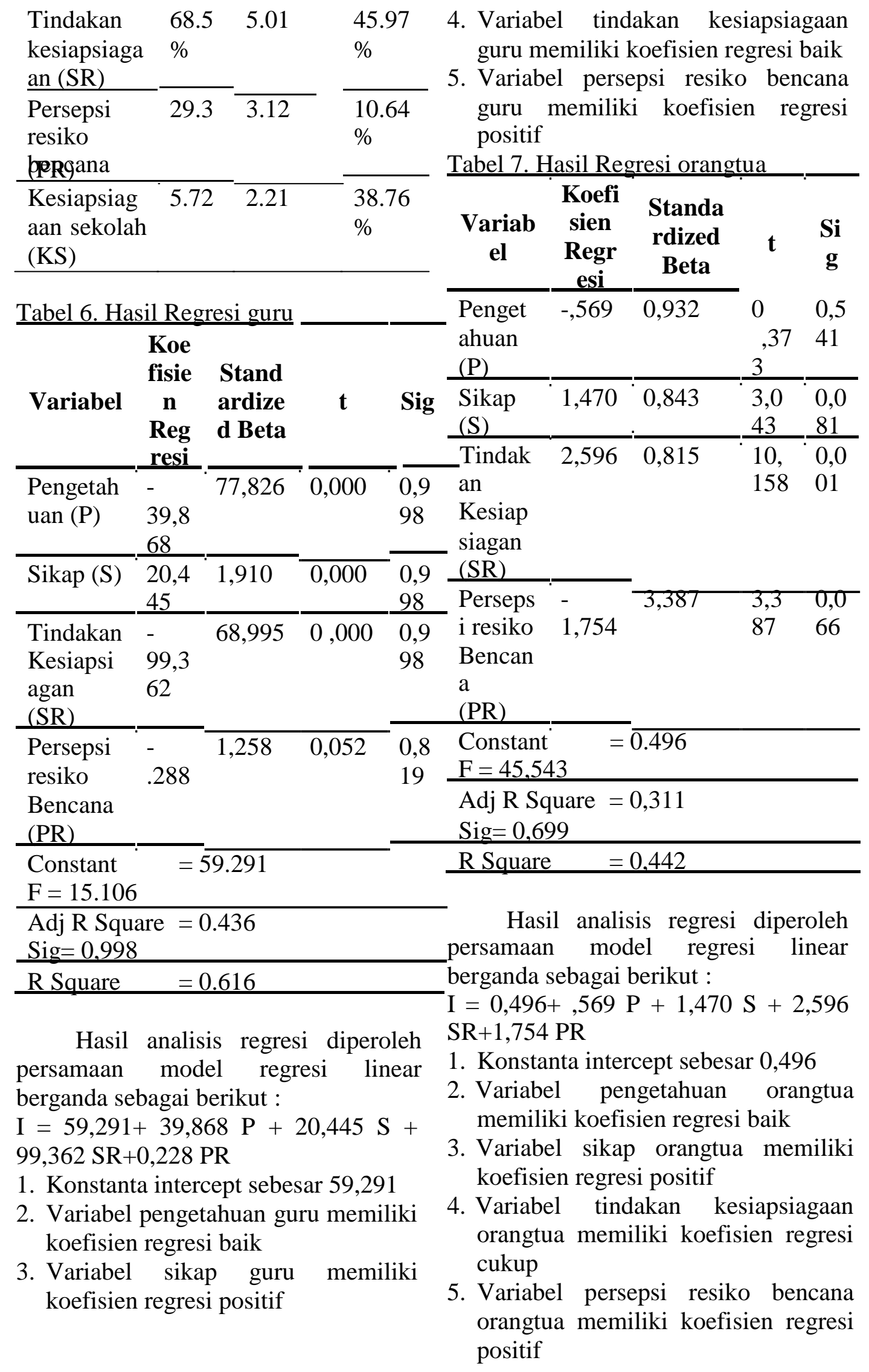


Hasil penelitian yang dilakukan menunjukkan bahwa pengetahuan yang dimiliki oleh guru dan orangtua didapatkan rerata hasil dalam kategori baik. Beberapa faktor pemungkin dari hal ini adalah latar belakang pendidikan yang dimiliki, usia serta kegiatan pelatihan / penyuluhan yang pernah mereka ikuti.

Notoatmodjo

mengemukakan bahwasanya peningkatan pengetahuan yang dimiliki oleh seorang individu akan memiliki korelasi dengan peningkatan perilaku dari individu tersebut. Hal ini dikarenakan individu yang menerima informasi baru yang bermanfaat bagi dirinya dan anggota keluarga yang dimiliki akan mulai memproses informasi baru tersebut. Selanjutnya individu akan menimbang baik dan buruknya dari informasi yang baru untuk selanjutnya melakukan evaluasi atas informasi tersebut. Tahap terakhir dari proses ini adalah mengimplementasikan informasi yang didapatkan oleh individu tersebut. Seseorang yang pernah mendapatkan informasi mengenai bencana atau kesiapsiagaan bencana, akan cenderung berperilaku positif dibandingkan dengan individu yang tidak pernah menerima informasi mengenai kesiapsiagaan bencana.

Usia yang dimiliki individu juga memiliki pengaruh yang cukup signifikan terhadap perilaku individu. Hurlock (2012) mengemukakan bahwasanya usia seseorang akan mempengaruhi kemampuan seseorang untuk berinteraksi dan bersosialisasi dengan orang lain di sekitarnya. Semakin dewasa usia yang dimiliki oleh seseorang maka, kesempatan yang dimiliki oleh individu untuk mendapatkan informasi akan semakin baik. Hal ini dikarenakan individu belajar dari setiap pengalaman yang pernah dialaminya. Dari hasil penelitian didapatkan bahwasanya responden pernah mengalami kondisi bencana banjir. Hampir tiap tahun mereka dihadapkan dengan kondisi yang serupa. Hal ini secara tidak langsung memotivasi mereka untuk berusaha bersosialisasi dengan lingkungannya untuk mendapatkan informasi yang dapat mereka manfaatkan untuk dirinya dan keluarganya.

Faktor terakhir adalah latar belakang pendidikan. Notoatmodjo (2012) mengemukakan, latar belakang pendidikan yang dimiliki oleh seorang individu akan mempengaruhi pola kehidupan dari individu itu sendiri. Semakin tinggi tingkat pendidikan yang dimiliki, maka semakin baik pula pengetahuan, perilaku, motivasi dan sikap yang dimiliki. Dari hasil penelitian didapatkan bahwa latar belakang pendidikan yang dimiliki oleh responden penelitian dalam kategori cukup yaitu latar belakang pendidikan SLTP / MTS. Seseorang yang pernah menempuh jenjang pendidikan, dalam dirinya akan terjadi proses sistematis terutama dalam berpikir. Hal ini dikarenakan selama mereka menempuh pendidikan, mereka diajarkan untuk melakukan analisa suatu permasalahan. Selanjutnya mereka juga diajarkan untuk melakukan evaluasi atas permasalahan yang terjadi untuk selanjutnya mereka harus melakukan penyimpulan mengenai permasalahan tersebut. Setelah mendapatkan kesimpulan, individu akan mulai mencoba untuk mendapatkan solusi atas permasalahan yang dihadapi. Adanya proses sistematis ini secara tidak langsung akan menjadikan individu semakin siap siaga dan tanggap dalam menghadapi kondisi bencana yang terjadi semisal bencana banjir. 
Sikap merupakan respon yang bersifat positif maupun negatif, pada sikap positif kecenderungan tindakan adalah mendekati menyenangi, mengharapkan obyek tertentu, sedangkan pada sikap negatif terdapat kecenderungan untuk menjauhi, menghindar, membenci, tidak menyukai obyek tertentu. sikap guru negatif dan sikap orangtua positif. Sikap yang ditunjukkan responden ketika terjadi banjir juga kurang baik hal ini dikarenakan setiap kali banjir belum faham apa yang akan dilakukan. Ketika terjadi banjir mereka memilih untuk bermain-main dengan air terutama siswa dan sebaliknya kecenderungan sikap positif adalah mendekati, menyenangi, mengharapkan objek tertentu menunjukan bahwa responden terutama untuk melakukan upaya pemantauan cuaca dan informasi banjir .

Tindakan kesiapsiagaan guru cukup dan orangtua baik, maka responden sudah mempunyai sikap positif yang menunjukan adanya kesesuaian dengan stimulus yaitu kesiapan menghadapi bencana. Sikap positif disebabkan oleh beberapa faktor diataranya adalah pengalaman dan adanya penyuluhan tentang kesiapsiagaan mengantisipasi ancaman banjir.( Azwar ,2011).

Dari pelatihan kebencanaan efektif meningkatkan pengalaman masyarakat tentang ancaman bencana dan seringnya terjadi banjir dalam satun kurang lebih 6 kali sampai 12 kali per satu tahunnya.

Persepsi resiko bencana guru dan orangtua positif.

Persepsi dipengaruhi oleh pemahaman tentang ancaman, sikap diri terhadap risiko, pengalaman sebelumnya, paparan terhadap kesadaran, kemampuan untuk mitigasi, dan karakteristik demografi (Enders,
2001). Pada responden guru dan orangtua, sesuai dengan hasil penelitian menunjukkan bahwa persepsi orangtua positif, hal ini diakibatkan karena rerata pengetahuan orangtua tentang ancaman banjir adalah baik, seluruh masyarakat memiliki pengalaman banjir sebelumnya serta pernah mendapatkan penyuluhan yang dapat meningkatkan kesadaran masyarakat untuk siap siaga terhadap ancaman banjir.

\section{SIMPULAN}

1. Tingkat pengetahuan guru dan orangtua di SDN Gebangmalang kecamatan mojoanyar kabupaten mojokerto terhadap kesiapsiagaan bencana banjir baik

2. Sikap guru di SDN Gebangmalang kecamatan mojoanyar kabupaten mojokerto terhadap kesiapsiagaan bencana banjir banyak yang bersikap negatif dengan kesiapsiagaan bencana yang tidak siap sedangkan sikap orangtua di SDN Gebangmalang kecamatan mojoanyar kabupaten mojokerto terhadap kesiapsiagaan bencana banjir banyak yang bersikap positif dengan kesiapsiagaan bencana yang siap

3. Tindakan kesiapsiagaan guru di SDN Gebangmalang kecamatan mojoanyar kabupaten mojokerto terhadap kesiapsiagaan bencana banjir cukup dengan kesiapsiagaan yang tidak siap sedangkan tindakan kesiapsiagaan orangtua di SDN Gebangmalang kecamatan mojoanyar kabupaten mojokerto terhadap kesiapsiagaan bencana banjir baik dengan kesiapsiagaan yang siap

4. Persepsi Resiko guru di SDN Gebangmalang kecamatan mojoanyar kabupaten mojokerto terhadap kesiapsiagaan bencana 
banjir sebagian besar memiliki persepsi yang negatif dengan kesiapsiagaan bencana tidak siap sedangkan persepsi resiko orangtua di SDN Gebangmalang kecamatan mojoanyar kabupaten mojokerto terhadap kesiapsiagaan bencana banjir sebagian besar memiliki persepsi yang positif dengan kesiapsiagaan bencana siap

\section{SARAN}

1. Bagi pemerintah Kabupaten Mojokerto dan Badan Penanggulangan Bencana Daerah (BPBD), diharapkan dapat bekerjasama dengan dinas pendidikan di wilayah kecamatan mojoanyar kabupaten mojokerto untuk memberikan sosialisasi dan informasi yang terintegrasi sehingga guru dan orangtua dapat mendapatkan awareness dan preparedness yang lebih baik untuk menghadapi ancaman bencana banjir di kecamatan Mojoanyar Kabupaten Mojokerto

2. Perlu diberikan penyuluhan atau simulasi kepada guru dan orangtua tentang kesiapsiagaan bencana banjir di semua fase bencana secara rutin dan terjadwal sesuai dengan kesepakatan dengan pemerintah, dinas pendidikan dan sekolahsekolah yang terkena ancaman bencana banjir untuk memberikan gambaran yang mendekati situasi sebenarnya agar tindakan atau respon masyarakat bisa lebih baik dalam menghadapi bencana banjir di kecamatan mojoanyar kabupaten mojokerto.

3. Bagi peneliti selanjutnya Untuk bisa Mengembangkan variabel penelitian dan lokasi yang di teliti lebih ekstrim lagi.
UCAPAN TERIMA KASIH

1. Dr. Setya Haksama., drg., M.Kes ,Fakultas Kesehatan Masyarakat universitas Airlangga Surabaya selaku pengajar program magister manajemen bencana dan sebagai pembimbing 1

2. Dr.

Makhfudli, S.Kep.Ns.,M.Ked.Trop, Fakultas Keperawatan Universitas Airlangga Surabaya selaku pembimbing 2

3. Dr. Christrijogo Sumartono W., dr., SpAn., KAR selaku pengajar program magister manajemen bencana dan sebagai Koordinator program studi magister manajemen bencana.

\section{RUJUKAN JURNAL}

1. Cindrawaty Lesmana, Nurul Purborini. Kesiapsiagaan Komunitas Sekolah dalam menghadapi bencana di Kabupaten Magelang, 2015

2. Peran Guru Terhadap Kesiapsiagaan Sekolah dalam menghadapi bencana banjir di kelurahan sewu kecamatan Jebres Kota Surakarta, 2013

\section{DAFTAR PUSTAKA}

Ajzen, I. (1991). "Theory of Planned Behavior". In Organizational Behavior and Human Decision Processes, 50, 179-211. From http://people .umass.edu/aizen. (Dinduh pada 20 September 2018).

Ajzen, I. (2005). Attitudes, Personality and Behavior, (2nd edition), Berkshire, UK: Open University Press-McGraw Hill Education.

Bakornas PB. $2007 . \quad$ Pengenalan Karakteristik Bencana dan Upaya Mitigasinya di Indonesia.Jakarta: Badan Nasional Penanggulangan Bencana.

Badan Penanggulangan Bencana Daerah Kab. Mojokerto. 2016 
Chairummi. 2013. Pengaruh Konsep Diri Dan Pengetahuan Siswa Terhadap Kesiapsiagaan Bencana Gempa Bumi Di SDN 27 dan MIN Merduati Banda Aceh. Program Studi Magister Ilmu Kebencanaan Program Pascasarjana Universitas Syiah Kuala Darussalam Banda Aceh. Diakses pada 28 September 2018.

DIBI, Badan Nasional Penanggulangan Bencana. (2015). Data Kebencaan di Indonesia

Enders, Jessica. 2001. Measuring Community Awareness and Preparedness for Emergencies. Australian Journal of Emergency Management, 2001_16(3):pp52-59.

Federal Emergency Management Agency. 2006. Citizen Corps Personal Behavior Change Model for Disaster Preparedness. Citizen Preparedness Review. Community Resilience Through Civic Responsibly and SelfReliance. FEMA B-728/July.

Gregg, C, E., Houghton, B. F., Johnston, D. M.,Paton, C., and Swanson, D. A. 2004. The perception of Volcanic Risk in Kona Communities from Mauna Loa and Hualalai Volcanoes, Hawaiki. Journal of Volcanology and Geothermal Research, 130, 179-196.

Hidayati, Deny, dkk. (2006). Kajian Kesiapsiagaan Bencana Masyarakat dalam Menghadapi Bencana Gempa dan Tsunami. Jakarta: LIPIUNESCO- ISDR.

Hurlock, Elizabeth B 2012, Psikologi Perkembangan Suatu Pendekatan Sepanjang Rentang Kehidupan. Edisi Kelima, Jakarta: Erlangga.

Jamaluddin, Badar.(2010). Konsep pengendalian Kawsan Rawan
Bencana Banjir Akibat Luapan Sungai Bengawan Solo, Tugas Akhir Mahasiswa

Perencanaan Wilayah dan Kota, Institut Teknologi Sepuluh Nopember, Surabaya.

LIPI - UNESCO/ISDR, 2006, Kajian

Kesiapsiagaan Masyarakat dalam

Mengantisipasi Bencana Gempa Bumi \& Tsunami, Deputi IlmuPengetahuan Kebumian Lembaga Ilmu Pengetahuan Indonesia, Jakarta

Lindell, M.K. and Whitney, M., 2000. Correlates of Household Seismic Hazard Adjusment Adoption. Risk Analysis.

Notoatmodjo, S. 2003. Pendidikan dan Perilaku Kesehatan. Jakarta: PT RINEKA CIPTA

Notoatmodjo, S. 2012. Promosi Kesehatan dan Perilaku Kesehatan. Jakarta: PT RINEKA CIPTA

Niekerk, v.D : USAID Disasters Risk Reduction Training Course for Southern Africa (2011): Introduction to disaster risk reduction. Diunduh pada 28 September 2018.

Nurjanah, dkk. 2011. Manajemen Bencana. Bandung: Alfabeta

Rante, Anshar. 2012. Tingkat Kesiapsiagaan Rumah Tangga Menghadapi Bencana Alam Tanah Longsor Di Kelurahan Battang Barat Kecamatan Wara Barat Kota Palopo Tahun 2012. Pascasarjana Universitas Hasanuddin Makassar

Suton, J., and Tierney, K. 2006. Disaster Preparendess: Concept, Guidance and Research, Colorado: University of ColoradoCoppola DP, Maloney EK.2009. Communicating Emegency Preparedness, Strategies for Creating a 
Disasters Resilient Public, Taylor \& Francis Group , ISBN 978-14200-6510-7.

Silvaranto, Teguh. 2014. Disertasi Penyusunan Model Penyiapan Kesiapsiagaan Kemandirian Dibidang Kesehatan Bagi Keluarga Daerah Rawan Bencana Gempa Tektonik Dan Tsunami. Fakultas Kedokteran Universitas Airlangga Surabaya.

Undang-Undang No. 24 Tahun 2007 tentang Penanggulangan Bencana

UN-ISDR. 2002. Living with Risk: A Global Review of Disaster Reduction Initiatives. Preapared as An Inter-Agency Effort
Coordinated by the ISDR Secretariat with special support from the Government of Japan, the World Meteorological Organization and the Asian Disaster Reduction

Wignyo Adiyoso dan Hidehiko Kanegae (2013), Efektivitas Dampak Penerapan Pendidikan Kebencanaan di Sekolah terhadap Kesiapsiagaan Siswa Menghadapi Bencana Tsunami di Aceh, Indonesia, Majalah.indd, Edisi 03/Tahun XIX/2013

Zainuddin, M. 2011. Metodologi kefarmasian dan Kesehatan. Surabaya: Pusat Penerbitan dan Percetakan Universitas Airlangga 